\title{
The Fifth Plenary Session: A Note on Recent Policy Initiatives and China's 11th Five-Year Plan
}

\author{
KJELD ERIK BRøDSGAARD
}

Keywords: Personnel changes, political institutionalization in China, Five-Year Plan, sustainable development, "new socialist countryside".

In October 2005 the 16th Central Committee of the Chinese Communist Party (CCP) held its 5th Plenary Session. The Central Committee usually meets every year in the fall in a plenary session that sets out major policy guidelines for the Chinese leadership. This time the most important task of the plenum was to review a draft proposal for 11th Five-Year Plan covering the period 2006-11 (CCP Central Committee Proposal on Formulating the 11th Five-Year Programme for National Economic and Social Development).

The 5th Plenary Session marked the first time that Hu Jintao was undisputably in charge of heading a major meeting of the top leadership in China. $\mathrm{Hu}$ Jintao assumed the position as party general secretary at the 16th Party Congress in November 2002, when Jiang Zemin stepped down after having served as party head since 1989. In March 2003 Jiang also handed over the post as president to Hu Jintao, but only in November 2004, at the 4th Plenum, did Jiang step down as chairman of the Central Military Commission (Brødsgaard 2004). In short this was the first plenary session where $\mathrm{Hu}$ Jintao appeared as formal head of both party and state as well as the military.

Prior to the conference it was rumoured that major personnel changes would be announced. Hong Kong sources reported that $\mathrm{Hu}$ Jintao would use the opportunity to consolidate his power by having Li Keqiang appointed to the politburo (Holbig 2005). The 50 year old Li Keqiang is party secretary of Liaoning Province and widely believed to be one of the most likely candidates to form the core of the new fifth generation that will take over when $\mathrm{Hu}$ Jintao retires at the 18th Party Congress in 2012. Li holds a PhD in Economics from Peking University and has made a career in the Communist Youth League, which is regarded as $\mathrm{Hu}$ Jintao's power base. Li Keqiang is former party secretary of Henan 
Province and was in December 2004 brought to the crisis-stricken Liaoning Province. He seems to have succeeded in restructuring the province and is apparently ready to move on to new assignments.

For some months there have also been speculations that $\mathrm{Hu}$ Jintao would fire the Shanghai party leader Chen Liangyu, who belongs to Jiang Zemin's so-called Shanghai faction. By retiring Chen, $\mathrm{Hu}$ Jintao would weaken Jiang Zemin's power base and further consolidate his own position. The most obvious candidate to succeed Chen Liangyu is Liu Yundong, who currently heads the CCP's United Front Department.

In the end, no major personnel changes took place in connection with the plenum. This can be taken as an indication of continued strength on behalf of Jiang Zemin and his Shanghai faction. However, it may also indicate that it is wrong to assume that there is a latent power struggle between $\mathrm{Hu}$ and Jiang. So far the transition from Jiang's third generation to Hu's fourth generation has taken place in an orderly and peaceful fashion without any major clashes. This is not to say that Hu is copying Jiang's urban and coastal-based strategies, but apparently policy differences can now be handled in a more professional and regularized fashion in China.

\section{1th Five-Year Plan}

The draft to the new Five-Year Plan reflects the new development strategy of $\mathrm{Hu}$ Jintao and Wen Jiabao. It is a strategy that is based on three important concepts that have been formulated and elaborated since the 16th Party Congress. These concepts are the 'scientific development concept' (kexue fazhanguan), 'taking the people as the foundation' (yiren wei ben) for development, and 'harmonious society' (hexie shehui).

The new strategy acknowledges that the one-sided focus on growth in recent years has had negative social, political and ecological consequences. A huge income gap between rural and urban areas, between rich coastal provinces and between new and old social groups has opened up, threatening the social fabric and political stability. The focus on quantitative development indicators has also resulted in a blind use of natural resources with adverse consequences for the environment. Instead a policy of balanced and coordinated development between rural and urban areas, between the economy and society, and between different regions will be adopted. This policy of balanced and coordinated development forms the core of the 'scientific development concept' and is closely related to the concept of 'taking people as the main foundation', 
which focuses on the qualitative and human-related aspects of social and economic change (Communique of the 3rd Plenary Session of the 16th Central Committee of the Chinese Communist Party).

The departure from the previous emphasis on the speed of GDP growth also involves a new focus on sustainable development. This means that in formulating economic policies, attention must be given to both short-term and long-term costs and gains and to the views and interests of all sections of society. Otherwise it will be impossible to achieve the new overarching social and political goal-a harmonious society (hexie shehui).

The concept of harmonious society was first propagated in the Resolution of the 16th Party Congress in November 2002 and further elaborated at the 4th Plenary Session of the 16th Central Committee in September 2004. ${ }^{1}$ In an important speech by Hu Jintao from February 2005, but only published in July 2005, the Chinese leader argues that harmonious society is the 'foundation for the consolidation of the governing capacity of the party and the realization of its leading role' (Hu Jintao 2005).

Associated with the new focus on a 'people-centred' development strategy are plans to implement a green GDP index system. The new system intends to provide a measure of the relationship between economic growth, welfare and environmental changes and it will place a premium on local cadres' success in addressing issues concerning medical care, education, recreation and environmental protection.

\section{Objectives and Goals}

Concrete objectives for economic and social development during the '11-5' period, as the 11th Five-Year Plan period is called in Chinese publications, include the following measures (CCP Central Committee Proposal on Formulating the 11th Five-Year Programme):

1. Doubling the 2000 per capita GDP in 2010.

2. Markedly improving efficiency in utilizing resources, including reducing energy consumption per unit of GDP by 20 percent by 2010.

3. Developing a number of major enterprises into internationally competitive companies with well-known brands.

4. Improving the market economic system and achieving a basic equilibrium in the balance of international payments.

5. Universalizing and consolidating nine-year compulsory education 
and developing a sound social security system.

6. Improving the income levels and the quality of life for urban and rural residents and keeping the overall price level stable.

7. Significantly improving living, transportation, educational, cultural, health and environmental conditions for the population.

8. Progress in building democracy, legal institutions and spiritual civilization.

9. Further advancing social order and production safety and making progress in building a harmonious society.

Per capita GDP in China in the year 2000 amounted to 7,086 yuan and given the present economic growth rate, it seems likely that the goal of doubling this figure to 14,172 yuan is realistic. In fact, at the end of 2004 , the per capita GDP had already increased by 51 percent to 10,561 yuan (Zhongguo tongji nianjian 2001: 49; Zhongguo tongji nianjian 2005: 51). With the recent adjustment of the China's GDP, which has resulted in an increase of about 17 percent, the goal will undoubtedly be reached well ahead of 2010.

More efficient use of resources might be more difficult to attain. However, given the present shortage of global energy resources, it is imperative to pay attention to this issue. According to official statistics, China consumes 4.3 times as much coal and electricity to produce US $\$ 1$ worth of GDP as the United States, 7.7 times as much as Germany and France and 11.5 times as much as Japan. Already green GDP and sustainable development have become part of the official policies and an integral part of the concept of harmonious society. However, it is doubtful whether the Chinese government would be willing to prioritize sustainable development over continued high growth.

The Chinese leadership realizes that economic competition between nations is in fact between each nation's large enterprises and groups. Wu Bangguo formulated the government's position in 1998 when he claimed that the US relies on General Motors, Boeing and Dupont and a batch of other multinational companies and stated that China's position in the international economic order to a large extent will be determined by whether or not China's large enterprises can develop a position in the international economic order. However, China's big SOEs are still comparatively small in terms of market capitalization, revenues, R\&D outlays etc. China only has three companies in the FT 500, which ranks firms by market capitalization and not a single one among the world's top 300 companies by R\&D expenditure (Nolan 2004: 19-20). However, the Chinese government has not given up, even though CNOOC's failed 
attempt to acquire the California-based oil company Unocal in the summer of 2005 shows the difficulties involved. The government has now put extra resources into helping their SOEs become big global players.

\section{'Building a New Socialist Countryside'}

One of the major historical tasks for the Chinese leadership is to improve conditions in the countryside. It is high time, since the situation in many rural areas is tense due to low income, lack of land and an appalling lack of basic health services. The Five-Year Plan stipulates it is necessary to build a new socialist countryside (jianshe shehui zhuyi xin nongcun). Measures to achieve this goal include increasing investment at all levels in agriculture and the rural areas, including expanding the scope of public finance. The new Five-Year Plan also calls on government at all levels to provide the necessary public services and introduce a new type of cooperative medical system. There is also a focus on universalizing a nine-year compulsory education system in rural areas and exempting students in rural areas from miscellaneous fees and providing them with free textbooks and boarding allowances.

The plan also calls for an effort to increase farm income. Since 1985 income differences between rural and urban areas have increased significantly, overturning the gains from agricultural reform in the late 1970s and the early 1980s. The widening income gap between city and countryside has turned China into one of the most unequal societies in Asia and has the potential of undermining the regime's legitimacy among the peasants. The new $\mathrm{Hu}$-Wen leadership has put the issues of the so-called 'three rural issues' (agriculture, rural areas and the farmers) at the top of its agenda, and in March 2005, in his report to the National People's Congress, Wen Jiabao announced a nation-wide exemption of agricultural taxes in 2005. The plan is to abolish all agricultural taxes within three years. Already many provinces have passed measures exempting the levy of agricultural tax. The Five-Year Plan confirmed these attempts to alleviate the situation in the countryside.

The most pressing issue in the rural areas concerns the land. Rapid industrialization and urbanization have caused the availability of arable land to drop from 113 million hectares in 1998 to 100 million hectares in 2003 and average per capita availability of farmland is below the Food and Agriculture Organization's (FAO's) critical threshold (0.05 ha). As a consequence of more and more arable land being expropriated by the 
authorities for industrial and housing construction and infrastructural projects, issues related to the use of land have become a major source of dispute. In 2003 alone 160,000 cases of illegal and arbitrary land requisition were uncovered and unauthorized construction activities encroached on $35,000 \mathrm{~km}^{2}$ of land-equivalent to the surface area of Taiwan. In some cases the disputes turned violently as, for example, in April 2005, when 20,000 peasants drove off 1,000 riot police in Zhejiang Province to defend their land from being expropriated by the authorities. Or when on 6 December 2005 the police opened fire against peasants in Dongzhou, who were protesting against the building of a power-plant on agricultural land; at least 20 protesters were killed. On this most pressing issue in the rural areas, the Five-Year Plan stipulates that 'it is necessary to uphold the most rigorous farmland protection system, accelerate the pace of reforming the land expropriation system, and strengthen the mechanism for paying reasonable compensation to farmers whose land has been expropriated' (Central Committee Proposal on Formulating the 11th Five-Year Program: 5).

Although a latecomer in global trade and commerce, China's economic performance in the last two decades has been phenomenal. China's average growth rate was on average 9.4 percent between 1979 and 2003 and increased to 9.5 percent in 2004 and 2005. New official estimates even mention growth rates of 10 and 10.1 percent in 2004 and 2005 respectively. China is now the world's fourth largest economy and will without doubt surpass the UK to become the world's third largest some time during 2006. It is also the third largest trading nation in the world and may at the end of next year surpass Japan to become the largest holder of foreign exchange reserves in the world.

China has during this period of time introduced many elements of a market economy. However, there are still some remnants of the old command economy. One of those remnants is the Five-Year Plan. Before the reform, five-year plans were mandatory and set rather detailed production targets. Now the Five-Year Plan serves only as a framework for policies or as a catalogue of issues that need to be addressed. All the other five-year plans were called 'jihua' in Chinese, whereas the term 'guihua' has been used this time. While both can be rendered as 'plan' in the English language, 'guihua' has a connotation of a draft or regulatory guidelines subject to reinterpretation and change, whereas 'jihua' often refers to a set of concrete plans. 


\section{Conclusion}

Rather than focusing on the numerical reductions and quantitative changes of the past, the Hu-Wen leadership has chosen to focus on qualitative change in its approach to governance and social and economic change. As a result a new development strategy has crystallized, based on a new concept of 'taking people as the foundation' (yi ren wei ben). Taking people as the main foundation underlies another important recent idea: the 'scientific development concept' (kexue fazhanguan).

The new concepts reject the idea that the physical growth of GDP is the sole basis on which to assess the success of development. Instead they propose a 'people-centred' development strategy that recognizes that the ultimate purpose of growth is to meet people's material and spiritual needs. The fulfilment of this strategy demands the implementation of a comprehensive and coordinated development designed to correct imbalances in key areas, including gaps between urban and rural areas, between regions, between economic and social development, between human development and environmental preservation and internal development and external affairs - the so-called five overarching plans (wuge tongchou).

China has on earlier occasions adopted a strategy of balanced development and 'macro-economic readjustment', most notably during the so-called readjustment and consolidation period in the early 1960s, when Deng Xiaoping and Chen Yun succeeded in putting the economy back on track after the disastrous Great Leap Forward of 1958-60. Also during this period there was an attempt to address imbalances in the economy and to privilege agricultural incomes and correct a one-sided focus on the industrial sector.

However, the stress on sustainable development is new, as is the official emphasis that economic policies should be based on considerations that prioritize human development and a number of green issues, such as environment, health and general material and spiritual welfare rather than continued high growth rates.

Kjeld Erik Brødsgaard is Professor and Director of the Asia Research Centre, Copenhagen Business School 


\section{NOTES}

1 In line with the concept of 'harmonious society', the Chinese leadership also advocates the so-called 'new three people's principles' (xin sanmin zhuyi) which is a play on the famous 'three people's principles' formulated by Sun Yatzen and constituting the ideological core of his Guomindang Party.

\section{REFERENCES}

Brødsgaard, Kjeld Erik 2004. 'Jiang Finally Steps Down: A Note on Military Personnel Changes and the Party's Governing Capability'. The Copenhagen Journal of Asian Studies 19: 82-88.

'CCP Central Committee Proposal on Formulating the 11th Five-Year Programme for National Economic and Social Development' 2005. Xinhua News, 21 October.

'Communiqué of the Third Plenary Session of the 16th Central Committee of the Chinese Communist Party' 2003. Xinhua News, 14 October.

Holbig, Heike 2005. 'Wissenschaftliches Enwicklungskoncept', 'Harmonische Gesellschaft' und 'Eigenständige Innovation': Neue partipolitische Prioritäten unter $\mathrm{Hu}$ Jintao'. China aktuell, XXXIV (6): 13-19.

$\mathrm{Hu}$ Jintao 2005. 'Zai shengbuji zhuyao lingdao ganbu tigao goujian shehuizhuyi hexie shehui nengli zhuanti yantao banshang de jianghua' (19 February 2005) (Speech for a special study group of leading cadres at the provincial and ministerial level on increasing the capacity to build a harmonious society). Renmin ribao, 27 June 2005.

Nolan, Peter 2004. China at the Crossroads. Cambridge: Polity Press.

Zhongguo tongji nianjian 2001. Beijing: Zhongguo tongji chubanshe.

Zhongguo tongji nianjian 2005. Beijing: Zhongguo tongji chubanshe. 